\title{
WHY WILLIAM OF MOERBEKE IS NOT THE AUTHOR OF 'HIS' GEOMANTIA (AND WHY THAT DOES NOT MAKE THE TEXT LESS INTERESTING)
}

\author{
PIETER BEULLENS \\ UNIVERSITY OF LEUVEN
}

Arguably the most intriguing item in William of Moerbeke's bibliography is a work entitled Geomantia. ${ }^{1}$ Among the plethora of translated ancient Greek philosophical and scientific texts, the treatise stands out as the only one for which William allegedly was the original author. It deals with a particular technique of divination that was rather popular in the later Middle Ages. ${ }^{2}$ The system allowed the practitioner to predict the future or interpret the past from randomly drawn points and lines on the ground.

The treatise is preserved in fifteen manuscripts, listed by Elisa Rubino who is preparing the critical edition. ${ }^{3}$ In the majority of these witnesses it is explicitly ascribed to William of Moerbeke. Thérèse Charmasson, who gave a survey of the entire genre, established the authorship of the Dominican translator on the basis of the virtual unanimity in the manuscripts' subscriptions. Recent publications do not challenge her initial judgement. Agostino Paravicini Bagliani seems to summarize what has become a communis opinio:

1 The point of reference is Willy Vanhamel, «Biobibliographie de Guillaume de Moerbeke », in Jozef Brams, Willy Vanhamel (eds.), Guillaume de Moerbeke. Recueil d'études à l'occasion du $700^{\circ}$ anniversaire de sa mort (1286), Leuven University Press, Leuven 1989 (Ancient and Medieval Philosophy, De Wulf-Mansion Centre. Series 1, 7), p. 301-383; Geomantia on p. 376-383.

2 ThÉRÈsE CHARMASSON, Recherches sur une technique divinatoire: la géomancie dans l'occident médiéval, Droz-Champion, Geneva-Paris 1980 (Centre de Recherches d'histoire et de philologie de la IV ${ }^{\mathrm{e}}$ section de l'École Pratique des Hautes Études, V: Hautes Études Médiévales et Modernes, 44); William's Geomantia is treated in chapter 6, p. 157-167.

3 Elisa RuBino, «Per una edizione della Geomantia di Guglielmo di Moerbeke: il testo del proemio e della prima distinzione della prima parte ", in Alessandro Palazzo, Irene Zavattero (eds.), Geomancy and Other Forms of Divination, SISMEL-Edizioni del Galluzzo, Firenze 2017 (Micrologus Library, 87), p. 93-134. 
La tradition manuscrite ne signale aucun autre nom d'auteur et aucun indice codicologique ou textuel faisant obstacle à la paternité de Guillaume de Moerbeke, ce qui induit aujourd'hui à pencher pour l'authenticité de cette attribution. ${ }^{4}$

The purpose of this note is to critically reassess the available data concerning the origin of the treatise. Arguments will follow the order of quotation above. They will cast serious doubts over the traditional attribution, yet also open up new lines of inquiry that seem to have been neglected so far.

While the information about the author's name is mostly accepted at face value, the colophons contain another element that should raise some degree of suspicion regarding their overall reliability. Three manuscripts give the year 1288 as the date for the completion of the text. Since William died two years earlier, there cannot be any doubt about the inaccuracy of this chronology. ${ }^{5}$ It is noteworthy to observe how several scholars have accepted Moerbeke's authorship as stated in the colophons, while at the same time proposing various solutions to ignore or correct the inconvenient date from those sources. ${ }^{6}$

When we turn to the manuscript tradition, several elements appear to deviate from the standard way in which William's translations were spread. All copies of the Geomantia except one are preserved in libraries from German-speaking areas. The tradition starts relatively late in the fourteenth century, which leaves the treatise with a geographically and chronologically more restricted dissemination than other works by William of Moerbeke. Admittedly, the value of this observation is somewhat outbalanced by the presence of three different French translations and one in Italian. They form a strong indication that the treatise was already known at an early stage in regions outside Central Europe. ${ }^{7}$

Another striking characteristic of the manuscript tradition of the Geomantia is that the variation among the fifteen extant copies is so important, that Rubino all but excludes the possibility to document the text in the form of a traditional critical edition. If she did, the critical apparatus would become 'elephantine'. Apparently, copyists attached a far lesser degree of authority to the Geomantia than to Latin versions of ancient masters. While William's translations were mostly copied with great care and few errors, the absence of a university

4 Agostino Paravicini Bagliani, « Le pénitencier pontifical Guillaume de Moerbeke. Deux nouveaux documents $(1268,1278)$ », in Francisco J. Hernández, Rocío SánChez Ameijeiras, Emma Falque (eds.), Medieval Studies in Honour of Peter Linehan, SISMEL-Edizioni del Galluzzo, Firenze 2018, p. 209223; see p. 221-222. I am extremely grateful to Steven Spileers, librarian of the KU Leuven Institute of Philosophy, who expertly got this article on my desk within hours after my request. VANHAMEL, « Biobibliographie », p. 317-318.

6 Ibid., p. 382. I did not find the title of sacre theologie professor in MS Kassel, Landesbibliothek, Astron. Qu. 16, as reported by PARAVICINI BAGLIANI, « Le pénitencier pontifical », p. 222.

7 Charmasson, Recherches sur une technique divinatoire, p. 166-167. 
tradition - where the academic authorities would control the quality of the exemplars - leads to important discrepancies among the manuscripts of this text, Rubino acknowledges. Moreover, the more practically orientated character of the Geomantia's content may equally account for the significant discrepancies between the extant copies. Concrete needs might have shifted the focus on specific information required by the user for whom the copy was made.

While these elements point to a rather atypical transmission history, they do not form undeniable arguments against the attribution of the Geomantia to William of Moerbeke. Alessandra Beccarisi therefore falls back on circumstantial evidence to underscore her claim to authenticity. ${ }^{8}$ Although she admits that there is no firm proof to ascribe the work with certainty to the Dominican translator, she implicitly aims to draw his intellectual background in such a way that his authorship would become acceptable.' William's concern for the influence of the heavenly spheres on the human life is proven by his translation of Ptolemy's Tetrabiblos. Witelo's description of William's scientific interests in the dedication of his Perspectiva confirms the latter's concern with higher powers and their effect on the fortune of living beings, with Neoplatonic philosophy, and with astrology. Another member of William's intellectual circle, Henry Bate of Mechelen, dedicated his work explaining the use of the astrolabe he had construed to his Dominican friend, leaving no doubt that the friar would have been fascinated by an instrument to observe celestial movements. In this line of thought, geomancy is to be considered as a less complicated form of astrology with similar objectives to interpret hidden signs of nature.

As a last argument in favour of authenticity, Beccarisi surveys Thomas Aquinas's treatment of divination in his treatise De sortibus, where he expertly describes the method of geomancy and discusses its possible value in the light of divine omnipotence. She plays down the possibility that Thomas's objections could have prevented William from writing a Geomantia.

William admittedly did not shy away on principle from every possibly sensitive subject regarding the prediction of the future, even if it may have led to frictions with a theological obstacle in the form of God's free will. A case in point is found in his translation of Ptolemy's Tetrabiblos, which surprisingly closes with an astrological table that allows readers to calculate their moment of death. ${ }^{10}$ It

8 ALESSANDRA BECCARISI, « Natürliche Prognostik und Manipulation: Wilhelm von Moerbeke De arte et scientia geomantiae ", in LORIS STURLESE (ed.), Mantik, Schicksal und Freiheit im Mittelalter, Böhlau, Köln-Weimar-Wien 2011 (Beihefte zum Archiv für Kulturgeschichte, 70), p. 109-127.

9 One could somewhat harshly speak of Beccarisi's methodology as flawed, since she consistently calls the text William's treatise, even in the section where her purpose specifically is to establish the authorship.

10 Gudrun Vuillemin-Diem, Carlos Steel, Pieter De Leemans, Ptolemy's Tetrabiblos in the Translation of William of Moerbeke. Claudii Ptolemaei Liber Iudicialium, Leuven University Press, Leuven 2015 (Ancient and Medieval Philosophy, De Wulf-Mansion Centre. Series 1, 19), p. 131-133. 
will remain ambiguous whether this material would have been deemed acceptable if the table had found a wider circulation than the unique manuscript in which it was preserved.

Although Beccarisi admits that no complete certainty about the authorship of William's Geomantia can be reached, she inexplicably leaves the linguistic approach totally unexplored. In this light, it is even more puzzling that Paravicini Bagliani explicitly claims that there is no codicological or textual objection to genuineness. Yet, Jozef Brams already suggested that features from the language used in the treatise strongly argue against the attribution. ${ }^{11}$ He singled out two characteristics in particular: first, the treatise contains several words that rather belong to vulgar Latin, typical of popular works and absent from William's translations; on the other hand, Brams spotted some phrasings that betray an Arabic background for the treatise. That may imply that the Geomantia was compiled from other material translated from an oriental original. ${ }^{12}$

As for the second argument, the same sources that bore testimony to William's interest in astrological science make it very unlikely that he would have used material supplied from Arabic. The editors of his translation of Ptolemy's Tetrabiblos describe how he declined to adopt the customary translation (h)yleg, a loan word from Arabic, for the Greek $\dot{\alpha} \varphi \varepsilon \tau \imath k o ́ s$, although it had become an accepted technical term in Latin astrology. William's choice for the Latin dimissorius made his version virtually incomprehensible for experts versed in the traditional vocabulary. Significantly, one of the rare users of the manuscript in which it was preserved added the more common term as an annotation to the neologism. ${ }^{13}$

The work of his friend Henry Bate confirms the general tendency to prefer pieces directly from the Greek to others with an Arabic background. Many instances can be found where he compares an identical passage in translations from different languages, invariably concluding that translatio que de Greco melius habet..$^{14}$ In a similar vein, Witelo in his dedication of the Perspectiva ascribes a feeling of taedium verbositatis Arabicae to William. The reference is usually

11 JOzEF BRAMS, « Mensch und Natur in der Übersetzungsarbeit Wilhelms von Moerbeke », in ALBERT Zimmermann, ANDREAS SPEer (eds.), Mensch und Natur im Mittelalter, vol. II, (Miscellanea Mediaevalia, 21/2), Walter de Gruyter, Berlin-New York 1991, p. 537-561, in particular p. 559560.

12 I cannot see how the acceptance of William's authorship can be reconciled with Charmasson's discovery that another treatise on geomancy is almost literally incorporated into the Geomantia ascribed to Moerbeke, see CHARMASSON, Recherches sur une technique divinatoire, p. 122. The problem is not mentioned by Beccarisi or Rubino.

13 Vuillemin-Diem, Steel, De Leemans, Ptolemy's Tetrabiblos, p. 31; the user was Simon Bredon, who incidentally also owned a copy of a Geomantia, see CHARMASSON, Recherches sur une technique divinatoire, p. 229.

14 Vuillemin-Diem, Steel, De Leemans, Ptolemy's Tetrabiblos, p. 39-44. 
interpreted as a warning against the lack of reliability of texts that had reached the Latin West through Arabic intermediaries. ${ }^{15}$ If William did not stick to this same attitude in his capacity of author and compiler of the Geomantia, it would have formed a complete denial of his customary stance and that of his intellectual peers.

When we turn to Brams's remark about the Latin vocabulary, it clearly needs to be applied with due reserve. It is conceivable that Moerbeke as a translator prefers a different linguistic register from that of William as an original author. However, the vocabulary from the short extract published in Rubino's article already offers a few unexpected lexical choices to supplement the terms that Brams judged to be suspect. One would expect Moerbeke not to use hesitatio and dilucide rather than dubitatio and palam or manifestum. ${ }^{16}$ Among the words for which the preference depends on habit and automatization the four instances of atque in the published passage look significant. This copula is virtually absent from Moerbeke's works, and when it does appear, it usually occurs in his revisions of prior translations. ${ }^{17}$ Similar relevance may be granted to the use of the passive perfect incepta est, which Moerbeke never introduces on his own strength. In his translations of Aristotelian texts, it appears just once in his revision of the Physica vetus, where he leaves the words of James of Venice unchanged. ${ }^{18}$

Obviously, these observations are open to interpretation and criticism. Only if Latin renderings of Greek text can be compared to each other, irrefutable conclusions become possible. Surprisingly, the published sample from the Geomantia contains a useful instance where the author explains the etymology of the term geomantia: dicitur a geos quod est terra et mantia divinatio. ${ }^{19}$ For the second part of the compound, divinatio is the translation of $\mu \alpha v \tau \varepsilon i \alpha$ that one may expect from William's quill. However, knowledge of Greek is no absolute requirement to make the connection, since everyone could learn from Isidore of Seville's Etymologiae VIII.9.11: $\mu \alpha v \tau \varepsilon i \alpha$ divinatio nuncupatur. As for the explanation for the first part, where geos is proposed to render the Greek for terra, every beginner will notice that this is not a suitable transcription of $\gamma \tilde{\eta}$. William may have made divergent lexical choices as an author, but he cannot suddenly have lost his Greek. At that point, a variant reading can come to the rescue: MS Wien,

15 Clemens BaeumKer, Witelo, ein Philosoph und Naturforscher des XIII. Jahrhunderts, Aschendorff, Münster 1908 (Beiträge zur Geschichte der Philosophie und Theologie des Mittelalters, 3/2), p. $128,1.28-29$.

16 Rubino, Per una edizione, p. 106 and 114.

17 I retrieved two occurrences of atque in the Physica and five in the Parva Naturalia (treatises on sleep) from the Aristoteles Latinus database (via <www.brepolis.net>, accessed December 2018).

18 Rubino, Per una edizione, p. 107; Physica, $236 \mathrm{~b} 36$.

19 Ibid., p. 116 
Nationalbibliothek, 3059, has dicitur a ge grece, quod est terra. ${ }^{20}$ However, this choice would turn the editorial process into a chance game, where variants are preferred according to the editor's convenience, because in what follows the Wien MS twice reads mantos instead of mantia. Moreover, the combination geos quod est terra seems firmly rooted in the Latin tradition. It is found in Thomas Aquinas's In II Sententiarum 8.1.6, with other similar occurrences in extremely popular texts as the Historia scholastica and the Legenda aurea.

As a final argument against William's paternity, it seems highly improbable that a society in which the wife, uxor, and the mistress, amasia, are mentioned on the same level was compatible with the views of William of Moerbeke, papal penitentiary. ${ }^{21}$

None of the previous aspects is in itself decisive to deny William of Moerbeke the authorship of the Geomantia. Some of the analysed readings may even be due to accidents in the transmission of the text, which would make them loose their critical value. Their sum, however, is too important to be brushed away without further investigation.

Moreover, would a negative judgement regarding the authenticity necessarily deprive the treatise of its inherent value? On the contrary, a careful assessment of the manuscripts' attribution may open up new perspectives for additional research. William's name was one among many used to attribute credibility to typical works from a genre for which the appropriateness was not beyond questioning. ${ }^{22}$ It would be interesting to explore the geographical and cultural context where a reference to his name and function at the papal court carried enough weight to counterbalance a content of dubious acceptability.

20 Pace Rubino, the manuscript reads grece in both parts that contain the text (fol. 93v and 136v), as opposed to her reading geomante (Rubino's sigla W1 and W2; MS checked on microfilm and via <http://digital.onb.ac.at/RepViewer/viewer.faces?doc=DTL_5957055\&order=1\&view=SINGL E>, accessed December 2018; see also CHARMASSON, Recherches sur une technique divinatoire, p. 13.

21 BecCARISI, Natürliche Prognostik und Manipulation, p. 126: «De amasia vel uxore, si [...] habeat amatorem. Si uxor vel amasia recuperabitur amissa re ». For what the comparison is worth, William in his capacity of penitentiary uses the word concubina, which obviously may have a different connotation than amasia, see PARAVICINI BAGLIANI, Le pénitencier pontifical, p. 213.

22 Charmasson, Recherches sur une technique divinatoire, p. 227 cites Hugo of Santalla, Gerard of Cremona, Plato of Tivoli, Michael Scot, Salio of Padua, and William of Moerbeke as translators to whom treatises on geomancy were attributed. She adds: « Le fait que les œuvres de Michel Scot, de Jean de Murs et de Pierre de Padoue soient vraisemblablement apocryphes, n'a que peu d'importance; l'attribution de géomancies à des personnalités de ce type montre qu'elles étaient susceptibles, aux yeux des contemporains, de les avoir écrites ». Andrea Robiglio kindly pointed out to me that there is a similar problem of authenticity with (in particular several alchemical) works attributed to Thomas Aquinas, see the list of 56 unechte Schriften compiled by Ruedi Imbach in Alexander Brungs, Vilem Mudroch, Peter Schulthess (eds.), Grundriss der Geschichte der Philosophie. Begründet von Friedrich Überweg, völlig neu bearbeitete Ausgabe. Die Philosophie des Mittelalters, vol. IV: 13. Jahrhundert. Schwabe, Basel 2017, p. 332-336. 